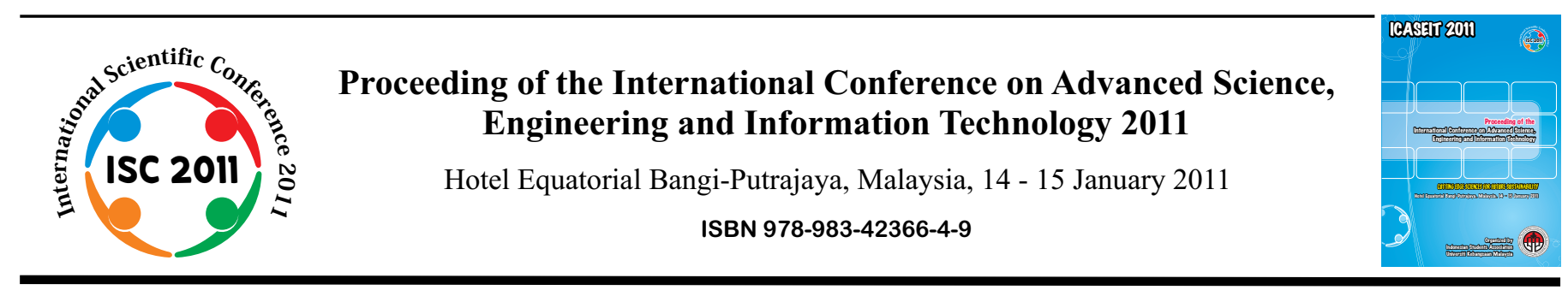

\title{
Energy Economical and Environmental Analysis of Industrial Boilers Using Fuel Switching
}

\author{
${ }^{1}$ Department of Mechanical Engineering \\ University Malaya, 50603 \\ E-mail: a_atabani2@msn.com \\ ${ }^{2}$ Department of Mechanical Engineering, \\ Polytechnic Negeri Medan, 20155 \\ Medan, Indonesia \\ E-mail: ardinsu@yahoo.co.id
}

Abdelaziz Emdeldin Atabani ${ }^{1}$, Saidur Rahman ${ }^{1}$, Arridina Susan Silitonga ${ }^{1,2}$, Abdi Hanra Sebayang ${ }^{2}$

\begin{abstract}
The successful implementation of the industrialization plan in Malaysia in 1985 has led to change this country from an agricultural economy into industrial based economy. The industrial sector represents the highest consuming sector across all other sectors and accounts for about $\mathbf{4 8 \%}$ of all total energy demand. This study is concerned with an energy saving, economic and environmental analysis of industrial boilers in Malaysian paper and pulp industries when applying the concept of fuel switching. It has been found that 11,946 ton of $\mathrm{CO}_{2}$ and $\mathrm{RM} 1,872,532$ could be saved annually, when switching between diesel fuel and biomass by a percentage of $50 \%$ for both instead of using $100 \%$ of diesel fuel. Also it has been found that 7,495,640 $\mathrm{kg}^{\circ} \mathrm{CO}_{2}$ and $\mathrm{RM} 923,431$ could be saved annually, when switching between diesel fuel and natural gas by a percentage of $50 \%$ for both instead of using $100 \%$ of diesel fuel. All these results represent high energy saving, environmental and economic benefits for a small developing country like Malaysia.

Keyword: Energy saving, economic benefits, environmental analysis, industrial boilers, fuel switching.
\end{abstract}

\section{INTRODUCTION}

\section{A. Energy demand trend in Malaysia}

One of the recent studies has shown that Malaysian economy grew at 5\% in 2005 [1]. Between 2000 and 2005, final energy consumption grew at a fast rate of $5.6 \%$ to reach 38.9 Mtoe. The final energy consumption is expected to reach 98.7 Mtoe in 2030, nearly three times the 2002 level as shown in Figure 1. The industrial sector will have the highest growth rate of $4.3 \%$, followed by transport at $3.9 \%$, residential at $3.1 \%$ and commercial at $2.7 \%$ [2]. The most striking feature among all Malaysian sectors' consumption is that the industrial sector accounted for some $48 \%$ of total energy use in 2007 which represents the highest percentage among all other sectors as shown in Figure 2[3].

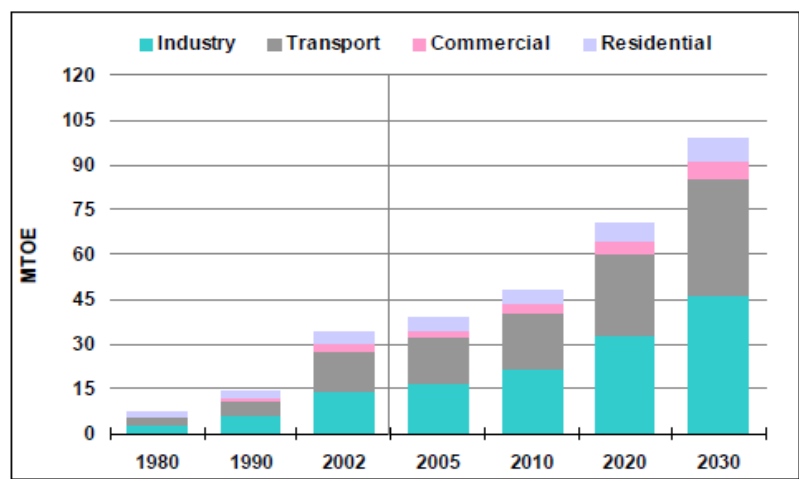

Figure 1 Statistics of energy uses in Malaysia from 1980-2030 [2]

In 2005, the statistics show that oil reserves are expected to last another 19 years while natural gas reserves are expected to last for about 33 years. As a result of the growing energy consumption (Figure 1) and domestic energy supply constraints, Malaysian government formulated the National Depletion Policy in 1980 which set 
the daily limit of oil and gas production levels. This policy has set the concept of sustainable development and diversification of energy sources as the main energy policy goals. The Five-Fuel Strategy has recognizes renewable energy resources (RE) as the economy's fifth fuel after oil, coal, natural gas and hydro in the long term. Nevertheless, substantial governmental intervention and support are necessary to implement this policy [2]. This papers aims to study energy saving, emissions reduction and cost benefits analysis when applying fuel switching approach in industrial boilers in Malaysian. The outcome of this study is expected to give the operators and policy makers many useful choices in many applications.

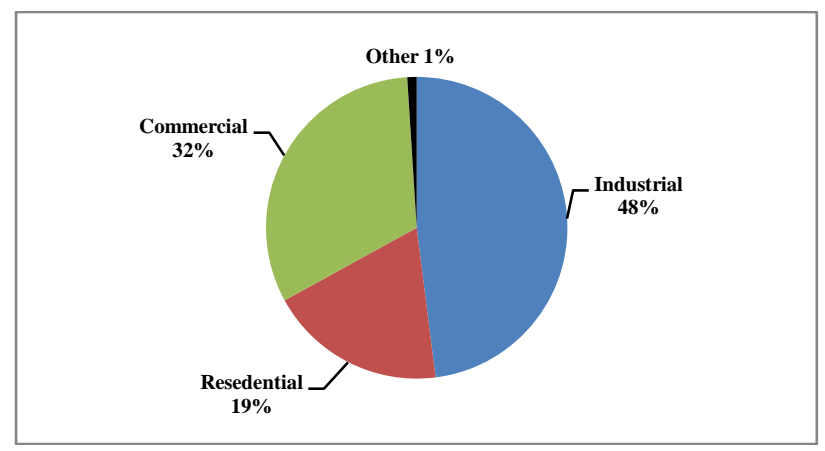

Figure 2 Statistics of energy uses in Malaysia in 2007 [3]

B. Fuel switching using biomass

Fuel switching can be defined as an emission control measure that involves the exchange of a less pure fuel to a cleaner one, also it can be defined as the use of alternative fuel or the substitution of one type of fuel for another, especially the use of a more environmentally friendly fuel as a source of energy in place of a less environmentally friendly one. This will help to reduce energy cost and emissions production.

In Malaysia it has been found that the gradual fuel substitution for electricity generation from harmful fossil fuels to less harmful fuels such as natural gas and renewable fuels such as hydro and biomass will contribute to $\mathrm{CO}_{2}$ reduction for about 167,618,280 ton from 2001-2020 as shown in Figure 3 [4].

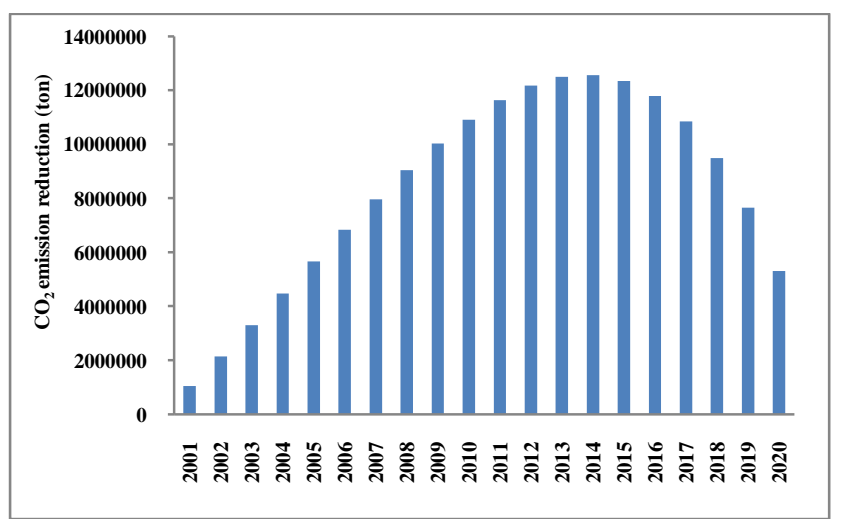

Figure 3 Potential $\mathrm{CO}_{2}$ reduction due to the changes of energy sources for electricity generation in Malaysia [4]

For the switching to occur, several conditions have to be fulfilled. First, an economical incentive must be present for customer, which means alternative fuels must be offered in a good and competitive price in comparison to conventional types. Second, the physical and technical potential to implement fuel switching approach must exist such as dispatchability factor and technical modifications to the prime mover to suite the proposed type of alternative fuel $[5$, $6]$.

Biomass is the name given to the all earth's living matter and is the general term for material derived from growing plants or from animal manure. It is a rather simple term for all organic materials that originates from plants, trees, crops and algae. Biomass as the solar energy stored in chemical form in plant and animal materials is among the most precious and versatile resources on earth [7]. There are many benefits of using biomass including:

(i) Economic benefits: biomass could replace some of the money spent on oil.

(ii) Environmental benefits including:

- Preservation of agricultural land that otherwise would be sold for residential development or industrial use.

- Sustainable agricultural techniques for these crops can restore and ensure soil stability and health and minimize chemical residues and habitat destruction.

- Methane is 20 times more powerful greenhouse than $\mathrm{CO}_{2}$. Capturing methane from producers such as cows or rice fields and using it as fuel will significantly reduce this greenhouse gas.

- Increased carbon sequestering from the crops grown for biomass.

- Use of waste from agricultural and timber industries.

- No net increase in atmospheric carbon dioxide.

In Malaysia, there is a good potential of using palm oil as a resource of biomass. Malaysia is regarded as the second largest producer of palm oil with 15.88 million tons; this represents $43 \%$ of the total world supply as shown in Figure 4. Currently palm oil represents $85.5 \%$ of total biomass production as shown in Figure 5 [8].

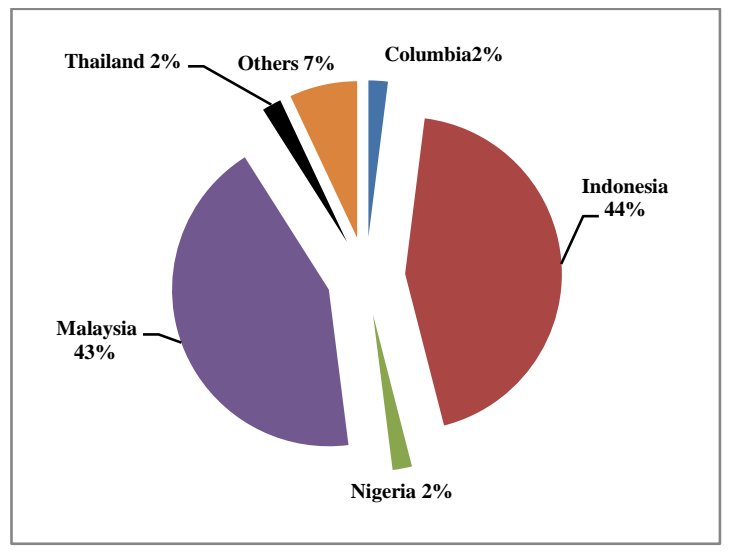

Figure 4 Top world producers of oil palm in 2006 [8] 


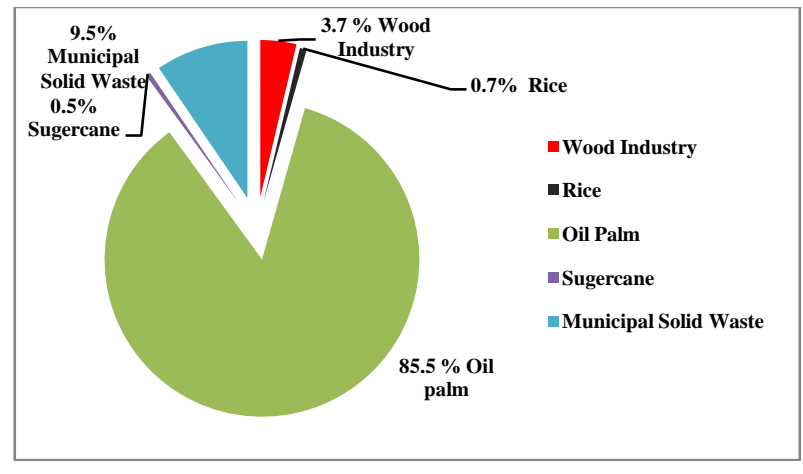

Figure 5 Biomass produced from different industry in Malaysia [8]

Sustainability of palm oil In Malaysia is judged by a body called Roundtable on Sustainable Palm Oil (RSPO). This body defines sustainable palm oil production as a legal, economically viable, environmentally appropriate and socially beneficial management and operations.

The environmental sustainability of oil palm biomass comes when burning it to generate energy. Based on current typical industry practices for palm oil production in Malaysia, using palm oil for bio-fuel applications renders an average net $\mathrm{CO}_{2}$ reduction of approximately $60 \%$. In other words, the $\mathrm{CO}_{2}$ emissions incurred in the palm oil supply chain are roughly $40 \%$ of the $\mathrm{CO}_{2}$ emissions avoided by replacing fossil fuels [9]. Recently some studies have shown that oil palm plantations are more effective carbon sink (an area of dry mass that is capable to absorb harmful greenhouse gases such as carbon dioxide) comparing to rainforest. Oil palm plantation assimilates up to 64.5 tons of carbon dioxide per hectare per year while virgin rainforest only can assimilate 42.2 tons per hectare per year [8].

Utilization of oil palm biomass could also ensure social sustainability by creating new employment opportunities in rural areas in the developing country like Malaysia. This is because labor requirement for biomass energy is relatively high, especially in the cultivation of energy crops [8].

\section{METODOLOGY}

A. Targeted manufacturing factories and audit data collection

The targeted industries in this paper are the paper and pulp. The necessary information to perform this study has been taken from PTM (Pusat Tenaga Malaysia) throughout a personal communication as shown in Table 1.

Table 1 Results of the industrial Malaysian energy audit [10]

\begin{tabular}{ccc}
\hline Factory name & Location & $\begin{array}{c}\text { Diesel consumption } \\
\text { (Liter/year) }\end{array}$ \\
\hline Tritex container & Selangor (Centre) & 359,100 \\
Cenpak holdings & Johor (South) & $1,363,000$ \\
Orna paper & Melaka (centre) & 102,000 \\
Genting sanyen & Selangor (Centre) & $1,972,000$ \\
Malaysian newsprint & Pahang (North) & 127,000 \\
Kym industries & Selangor (Centre) & 486,100 \\
\hline \multicolumn{2}{c}{ TOTAL } & $4,409,200$ \\
\hline
\end{tabular}

B. Cost saving of fuel switching

In this study two types of fuels have been suggested to switch with diesel in Malaysian paper and pulp industries. In Malaysia biomass and natural gas represent a very good choice to switch with diesel especially biomass as an abundant source. Table 2 shows fuel price, density and energy content of diesel, natural gas and biomass

Table 2 Prices, density and energy content of diesel, natural gas and biomass [11]

\begin{tabular}{cccc}
\hline Fuel type & Unit fuel price & $\begin{array}{c}\text { Density } \\
\left(\mathbf{k g} / \mathbf{m}^{\mathbf{3}}\right)\end{array}$ & $\begin{array}{c}\text { Energy content } \\
(\mathbf{k J} / \mathbf{k g})\end{array}$ \\
\hline Diesel & $1.002 \mathrm{RM} / \mathrm{Liter}$ & 0.85 & 45,000 \\
Natural gas & $0.6012 \mathrm{RM} / \mathrm{Liter}$ & 0.717 & 55,000 \\
Biomass & $15 \mathrm{RM} / \mathrm{Ton}$ & $\mathrm{N} / \mathrm{R}$ & 6,000 \\
\hline
\end{tabular}

- $\quad \mathrm{N} / \mathrm{R} \equiv$ Not Required

When using diesel as the main source of energy (100\%) in Malaysian paper and pulp's boilers the equations that used to calculate annual diesel energy consumption and fuel price are as follow:

$$
\begin{aligned}
& A D C_{k g}=A D C_{L} \times \rho_{D} \\
& A D C_{k J}=A D C_{k g} \times D E C \\
& A D C_{k W h}=\frac{A D C_{k J}}{3600} \\
& A D P_{R M}=A D C_{L} \times U F P_{D}
\end{aligned}
$$

When switching between diesel, natural gas and biomass in these boilers, annual energy consumption and fuel prices of diesel, biomass and natural gas will be as follow:

$$
\begin{aligned}
& A D C S_{k W h}=A D C_{k W h} \times \% D_{F S} \\
& A N G E C S_{k W h}=A D C_{k W h} \times \% N G_{F S} \\
& A B E C S_{k W h}=A D C_{k W h} \times \% B_{F S} \\
& A D C S_{L}=\frac{A D C S_{k W h} \times 3600}{\rho_{D} \times D E C} \\
& A D P S_{R M}=A D C S_{L} \times U F P_{D} \\
& A N G C S_{L}=\frac{A N G E C S_{k W h} \times 3600}{\rho_{N G} \times N G E C} \\
& A N G P S_{R M}=A N G C S_{L} \times U F P_{N G} \\
& A B C S_{k g}=\frac{A B E C S_{k W h} \times 3600}{B E C} \\
& A B P S_{R M}=A B C S_{k g} \times U F P_{B}
\end{aligned}
$$

Thus, total bill saving when applying fuel switching equals to the result of subtracting annual diesel fuel price without switching from the summation of annual diesel, 
natural gas and biomass fuel price when switching. Total annual bill saving can be represented as follow:

$T A B S_{R M}=A D P_{R M}-\left(A D P S_{R M}+A N G P S_{R M}+A B P S_{R M}\right)$

\section{Emissions reduction of fuel switching}

The environmental impact of the fuel switching methods is a potential reduction of greenhouse gasses or other elements which give negative impact to the environment. The common potential reductions include carbon dioxide $\mathrm{CO}_{2}$, sulfur dioxide $\mathrm{SO}_{2}$ and nitrogen oxide $\mathrm{NO}_{\mathrm{x}}$. This study is concerned with all these emissions when using natural gas and $\mathrm{CO}_{2}$ when using biomass. The emission factors of all these gases have already been shown in the Table 3 . The emissions production is a function of annual energy consumption and the emission factor of the particular fuel. Emissions production when burning diesel can be calculated as follow:

$$
\begin{aligned}
& A D E P_{\mathrm{CO}_{2}}=A D C_{k W H} \times E F_{\mathrm{CO}_{2}} \\
& A D E P_{\mathrm{NO}_{x}}=A D C_{k W H} \times E F_{\mathrm{NO}_{x}} \\
& A D E P_{\mathrm{SO}_{2}}=A D C_{k W H} \times E F_{\mathrm{SO}_{2}}
\end{aligned}
$$

Table 3 Emission factors of fossil fuels for electricity generation

\begin{tabular}{ccccc} 
& \multicolumn{5}{c}{$[12]$} \\
\hline \multirow{2}{*}{ Fuels } & \multicolumn{4}{c}{ Emission factor $(\mathbf{k g} / \mathbf{k W h})$} \\
\cline { 2 - 5 } & $\mathbf{C O}_{\mathbf{2}}$ & $\mathbf{S O}_{\mathbf{2}}$ & $\mathbf{N O}_{\mathbf{x}}$ & $\mathbf{C O}$ \\
\hline Coal & 1.18 & 0.0139 & 0.0052 & 0.0002 \\
Petroleum & 0.85 & 0.0164 & 0.0025 & 0.0002 \\
Gas & 0.53 & 0.0005 & 0.0009 & 0.0005 \\
Hydro & 0.00 & 0.0000 & 0.0000 & 0.0000 \\
Others & 0.00 & 0.0000 & 0.0000 & 0.0000 \\
\hline
\end{tabular}

When switching between diesel and natural gas in these boilers, annual emissions productions of $\mathrm{CO}_{2}, \mathrm{SO}_{2}$ and $\mathrm{NO}_{\mathrm{x}}$ depends on the percentage by which each fuel has been used and emission factor of each fuel. This can be expressed as follow:

$$
\begin{aligned}
& A D E P S_{\mathrm{CO}_{2}}=A D C S_{k W h} \times E F_{\mathrm{CO}_{2}} \\
& A D E P S_{\mathrm{SO}_{2}}=A D C S_{k W h} \times E F_{\mathrm{SO}_{2}} \\
& A D E P S_{\mathrm{NO}_{x}}=A D C S_{k W h} \times E F_{\mathrm{NO}_{x}} \\
& A N G E P S_{\mathrm{CO}_{2}}=A N G E C S_{k W h} \times E F_{\mathrm{CO}_{2}} \\
& A N G E P S_{\mathrm{SO}_{2}}=A N G E C S_{k W h} \times E F_{\mathrm{SO}_{2}} \\
& A N G E P S_{\mathrm{NO}_{x}}=A N G E C S_{k W h} \times E F_{N O_{x}}
\end{aligned}
$$

Annual emissions reduction of $\mathrm{CO}_{2}, \mathrm{SO}_{2}, \mathrm{CO}$ and $\mathrm{NO}_{\mathrm{x}}$ equals to the result of subtracting annual emissions production from the annual diesel and natural gas emissions production when switching depending on the percentage of each fuel used. This can be equal to

$$
\begin{aligned}
& A E R_{\mathrm{CO}_{2}}=A D E P_{\mathrm{CO}_{2}}-\left(A D E P S_{\mathrm{CO}_{2}}+A N G E P S_{\mathrm{CO}_{2}}\right) \\
& A E R_{\mathrm{SO}_{2}}=A D E P_{\mathrm{SO}_{2}}-\left(A D E P S_{\mathrm{SO}_{2}}+A N G E P S_{\mathrm{SO}_{2}}\right) \\
& A E R_{\mathrm{NO}_{x}}=A D E P_{\mathrm{NO}_{x}}-\left(A \mathrm{ADEPS} \mathrm{NO}_{\mathrm{X}}+\operatorname{ANGEPS}_{\mathrm{NO}_{x}}\right)
\end{aligned}
$$

When switching between diesel and biomass in these boilers, annual emissions productions of carbon dioxide depends on the percentage by which each fuel has been used and emission factor of biomass. It has been found that the $\mathrm{CO}_{2}$ emissions produced when burning biomass are roughly $40 \%$ of the $\mathrm{CO}_{2}$ emissions produced by fossil fuels [8]. Annual biomass emissions production of $\mathrm{CO}_{2}$ when switching can be expressed as follow:

$A B E P S_{C_{2}}=\left(A D E P_{C O_{2}}-A D E P S_{C O_{2}}\right) \times 0.4$

Thus, Annual emissions reduction of $\mathrm{CO}_{2}$ equals to the result of subtracting annual diesel emissions production before switching from annual diesel and biomass emissions production when switching depending on the percentage of each fuel used. This can be equal to:

$A E R_{\mathrm{CO}_{2}}=A D E P_{\mathrm{CO}_{2}}-\left(A D E P S_{\mathrm{CO}_{2}}+A B E P S_{\mathrm{CO}_{2}}\right)$

\section{RESULT AND DISCUSSION}

\section{A. Cost saving of natural gas and diesel switching}

Based on the input data in Tables 1 and 2, and equations (114), the results of total annual cost saving when switching between natural gas and diesel in different percentage are illustrated in Figures 6.

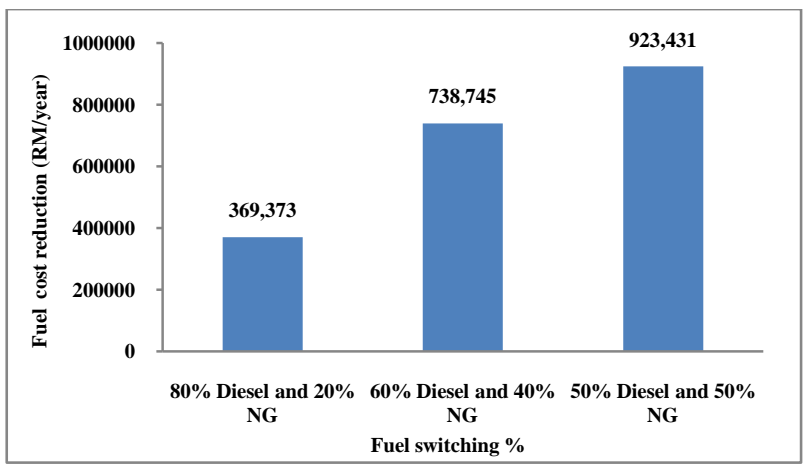

Figure 6 Total fuel cost reduction (RM/year) at different natural gas and diesel switching

The results in Figure 6 show that the total annual bill saving when switching in different percentage between natural gas and diesel in the Malaysian industrial boilers are about RM 369,373 in case of $80 \%$ diesel and $20 \%$ natural gas consumption, RM 738,745 in case of $60 \%$ diesel and $40 \%$ natural gas consumption and RM 923,431 in case of 50\% diesel and $50 \%$ natural gas consumption respectively. It can be observed that total annual bill saving increases with the increased percentage of natural gas consumption. These results represent a huge amount of annual bill saving that can be achieved when increasing the percentage of natural gas consumption in Malaysian industrial boilers.

B. Emissions reduction when switching between natural gas and diesel

Based on the input data in Table 3 and equations (1528 ), the results of annual emissions reduction of $\mathrm{CO}_{2}, \mathrm{NO}_{x}$ and $\mathrm{SO}_{2}$ when switching between natural gas and diesel are tabulated in Table 4. 
Table 4 Total emissions reduction $(\mathrm{kg})$ when switching between natural gas and diesel

\begin{tabular}{cccc}
$\begin{array}{c}\text { Fuel switching } \\
\text { percentage }\end{array}$ & $\begin{array}{c}\mathbf{8 0 \%} \text { diesel } \\
\text { and 20\% NG }\end{array}$ & $\begin{array}{c}\mathbf{6 0 \%} \text { diesel } \\
\text { and 40\% NG }\end{array}$ & $\begin{array}{c}\mathbf{5 0 \%} \text { diesel and } \\
\mathbf{5 0 \%} \mathbf{~ N G}\end{array}$ \\
\hline $\mathrm{CO}_{2}$ reduction & $2,998,256$ & $5,996,512$ & $7,495,640$ \\
$\mathrm{SO}_{2}$ reduction & 148,976 & 297,952 & 372,440 \\
$\mathrm{NO}_{x}$ reduction & 14,991 & 29,983 & 7,478
\end{tabular}

The results in Table 4 show that the total emission reduction of $\mathrm{CO}_{2}, \mathrm{NO}_{\mathrm{x}}$ and $\mathrm{SO}_{2}$ when switching in different percentage between natural gas and diesel are about $2,998,256 \mathrm{~kg}, 14,991 \mathrm{~kg}$ and 148,976 kg respectively in case of $80 \%$ diesel and $20 \%$ natural gas consumption. In case of $60 \%$ diesel and $40 \%$ natural gas consumption, the total annual emission reduction of $\mathrm{CO}_{2}, \mathrm{NO}_{\mathrm{x}}$ and $\mathrm{SO}_{2}$ are about $5,996,512 \mathrm{~kg}, 29,983$ and 297,952 respectively. Finally in case of $50 \%$ diesel and $50 \%$ natural gas consumption, the total annual emission reduction of $\mathrm{CO}_{2}, \mathrm{NO}_{\mathrm{x}}$ and $\mathrm{SO}_{2}$ are about $7,495,640 \mathrm{~kg}, 37,478 \mathrm{~kg}$ and $372,440 \mathrm{~kg}$ respectively. It can be observed that total emissions reduction increase with the increased percentage of natural gas consumption. These results represent a huge amount of total emissions reduction that can be achieved when increasing the percentage of natural gas consumption in Malaysian industrial boilers.

C. Cost saving of biomass and diesel switching

Based on the input data in Table 1 and 2 and equations (1-14), the results of total annual bill saving when switching between biomass and diesel are illustrated in Figures 7 .

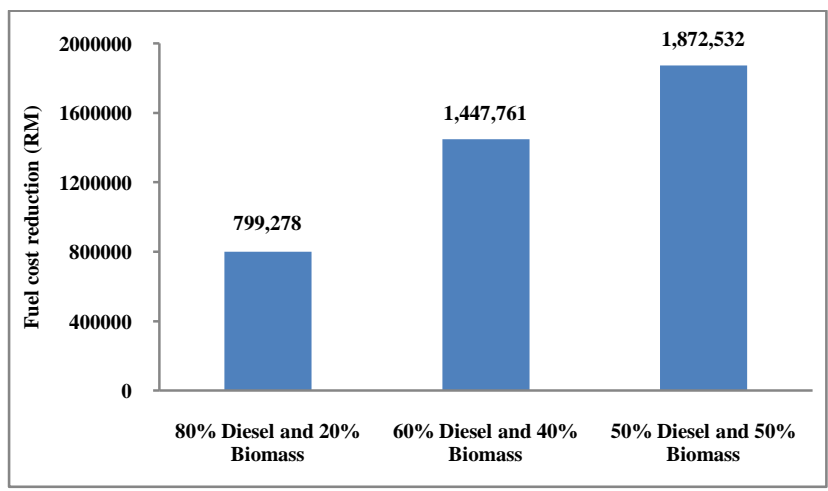

Figure 7 Total fuel cost reduction (RM/year) when switching between biomass and diesel

The results in Figure 7 show that the total annual bill saving when switching in different percentage between biomass and diesel in the Malaysian industrial boilers are about RM 799,278 in case of $80 \%$ diesel and $20 \%$ biomass consumption, RM 1,447,761 In case of $60 \%$ diesel and $40 \%$ biomass consumption and RM 1,872,532 in case of $50 \%$ diesel and $50 \%$ biomass consumption respectively. It can be observed that total annual bill saving increases with the increased percentage of biomass consumption. These results represent a huge amount of annual bill saving that can be achieved when increasing the percentage of biomass consumption in Malaysian industrial boilers.

D. Emissions reduction of biomass and diesel switching

Based on the input data in equations (15-28), the results of total annual emission reduction of $\mathrm{CO}_{2}$ when switching between biomass and diesel are illustrated in Figures 8 .

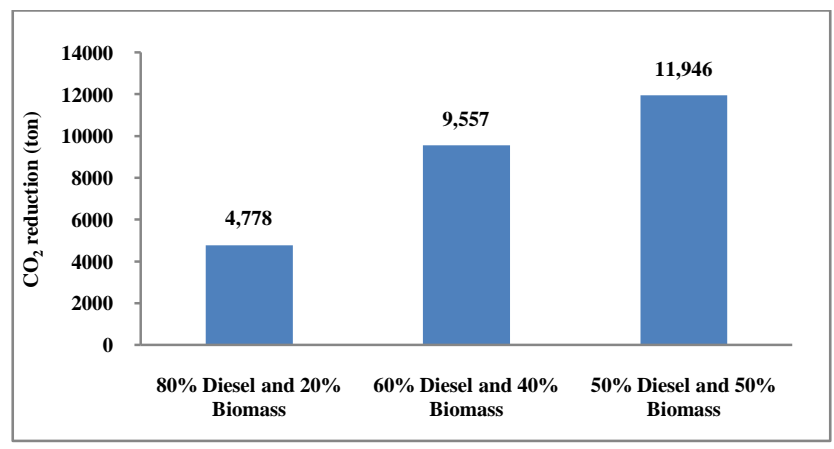

Figure 8 Total $\mathrm{CO}_{2}$ reduction (ton) when switching between biomass and diesel

The results in Figure 8 show that the total emission reduction of $\mathrm{CO}_{2}$ when switching in different percentage between biomass and diesel are about 4,778 ton in case of $80 \%$ diesel and $20 \%$ biomass consumption, 9,557 ton in case of $60 \%$ diesel and $40 \%$ biomass and 11,946 ton in case of $50 \%$ diesel and $50 \%$ biomass consumption. It can be observed that total emissions reduction increase with the increased percentage of biomass consumption. These results represent a huge amount of total emissions reduction that can be achieved when increasing the percentage of biomass consumption in Malaysian industrial boilers.

From the results that have been obtained in section A and $\mathrm{B}$ respectively, it has been found that total annual cost saving is higher when switching between diesel and biomass than diesel and natural gas. For instance, RM 1,872,532 can be saved annually in case of $50 \%$ diesel and $50 \%$ biomass fuel switching, however in case of $50 \%$ diesel and $50 \%$ natural gas RM 923,431 could be saved annually.

Carbon dioxide reduction is an another evidence of the advantage of using biomass over natural gas with 11,946 ton of $\mathrm{CO}_{2}$ reduction in case of $50 \%$ diesel and $50 \%$ biomass fuel switching and 7,496 ton reduction in case of $50 \%$ diesel and $50 \%$ natural gas fuel switching.

Also this study confirms the results in the literature which stated that when utilities switch to other renewable energy sources, such as biomass, substantial emissions reduction could be achieved

\section{CONCLUSION AND RECOMMENDATIONS}

The principle of fuel switching has been applied in this study, it has been found that total annual cost saving is higher when switching between diesel and biomass than diesel and natural gas. For instance, RM 1,872,532 can be saved annually in case of $50 \%$ diesel and $50 \%$ biomass fuel switching, however in case of 50\% diesel and 50\% natural gas RM 923,431 could be saved annually. Carbon dioxide reduction is another evidence of the advantage of using 
biomass over natural gas with 11,946 ton of $\mathrm{CO}_{2}$ reduction in case of $50 \%$ diesel and $50 \%$ biomass fuel switching and 7,496 ton reduction in case of $50 \%$ diesel and $50 \%$ natural gas fuel switching. This study satisfies the results in the literature which stated that when utilities switch to other renewable energy sources, such as biomass, substantial emissions reduction could be achieved

\section{NOMENCLATURE}

\begin{tabular}{|c|c|}
\hline$A B C S_{K g}$ & Annual biomass consumption when switching (kg/year) \\
\hline $\mathrm{ABECS}_{\mathrm{kWh}}$ & $\begin{array}{l}\text { Annual biomass energy consumption when switching } \\
\text { (kWh/year) }\end{array}$ \\
\hline $\mathrm{ABEPS}_{\mathrm{CO}_{2}}$ & $\begin{array}{l}\text { Annual biomass emissions production of } \mathrm{CO}_{2} \text { when } \\
\text { switching (kg/year) }\end{array}$ \\
\hline $\mathrm{ABPS}_{\mathrm{RM}}$ & Annual biomass price when switching (RM/year) \\
\hline $\mathrm{ADC}_{\mathrm{kg}}$ & Annual diesel consumption (kg/year) \\
\hline $\mathrm{ADC}_{\mathrm{L}}$ & Annual diesel consumption (Liter/year) \\
\hline $\mathrm{ADCS}_{\mathrm{L}}$ & Annual diesel consumption when switching ( $\mathrm{kg} / \mathrm{year})$ \\
\hline $\mathrm{ADCS}_{\mathrm{kWH}}$ & $\begin{array}{l}\begin{array}{l}\text { Annual diesel energy consumption when switching } \\
(\mathrm{kWh} / \mathrm{year})\end{array} \\
\end{array}$ \\
\hline $\mathrm{ADC}_{\mathrm{kJ}}$ & Annual diesel energy consumption (kJ/year) \\
\hline $\mathrm{ADC}_{\mathrm{kWH}}$ & Annual diesel energy consumption (kWh/year) \\
\hline $\mathrm{ADP}_{\mathrm{RM}}$ & Annual diesel price (RM/year) \\
\hline $\mathrm{ADPS}_{\mathrm{RM}}$ & Annual diesel price when switching (RM/year) \\
\hline $\mathrm{ABPS}_{\mathrm{RM}}$ & Annual biomass price when switching (RM/year) \\
\hline $\mathrm{ADCS}_{\mathrm{kWH}}$ & $\begin{array}{l}\text { Annual diesel energy consumption when switching } \\
(\mathrm{kWh} / \mathrm{year})\end{array}$ \\
\hline $\mathrm{AER}_{\mathrm{CO}_{2}}$ & Annual emissions reduction of $\mathrm{CO}_{2}$ (kg/year) \\
\hline ANGECS $_{\mathrm{kWh}}$ & $\begin{array}{l}\text { Annual natural gas energy consumption when switching } \\
(\mathrm{kWh} / \mathrm{year})\end{array}$ \\
\hline $\mathrm{ANGPS}_{\mathrm{RM}}$ & Annual natural gas price when switching (RM/year) \\
\hline $\mathrm{ADEP}_{\mathrm{CO}_{2}}$ & $\begin{array}{l}\text { Annual diesel emissions production of } \mathrm{CO}_{2} \text { when } \\
\text { switching }(\mathrm{kg} / \text { year) }\end{array}$ \\
\hline $\mathrm{ADEP}_{\mathrm{NOx}}$ & Annual diesel emissions production of $\mathrm{NO}_{\mathrm{x}}(\mathrm{kg} / \mathrm{year})$ \\
\hline $\mathrm{ADEP}_{\mathrm{SO}_{2}}$ & Annual diesel emissions production of $\mathrm{SO}_{2}(\mathrm{~kg} / \mathrm{year})$ \\
\hline$A D E P S_{C O_{2}}$ & $\begin{array}{l}\text { Annual diesel emissions production of } \mathrm{CO}_{2} \text { when } \\
\text { switching }(\mathrm{kg} / \text { year) }\end{array}$ \\
\hline ADEPS $_{\mathrm{CO}}$ & $\begin{array}{l}\text { Annual diesel emissions production of } \mathrm{CO} \text { when } \\
\text { switching (kg/year) }\end{array}$ \\
\hline $\operatorname{ADEPS}_{\mathrm{NO}_{\mathrm{x}}}$ & $\begin{array}{l}\text { Annual diesel emissions production of } \mathrm{NO}_{\mathrm{x}} \text { when } \\
\text { switching }(\mathrm{kg} / \mathrm{year}\end{array}$ \\
\hline $\mathrm{ADEPS}_{\mathrm{SO}_{2}}$ & $\begin{array}{l}\text { Annual diesel emissions production of } \mathrm{SO}_{2} \text { when } \\
\text { switching (kg/year) }\end{array}$ \\
\hline ANGEPS $_{\mathrm{NO}_{\mathrm{x}}}$ & $\begin{array}{l}\text { Annual natural gas emission production of } \mathrm{NO}_{\mathrm{x}} \text { when } \\
\text { switching (kg/year) }\end{array}$ \\
\hline $\mathrm{ANGEPS}_{\mathrm{CO}_{2}}$ & $\begin{array}{l}\text { Annual natural gas emission production of } \mathrm{CO}_{2} \text { when } \\
\text { switching (kg/year) }\end{array}$ \\
\hline ANGEPS $_{\mathrm{SO}_{2}}$ & $\begin{array}{l}\text { Annual natural gas emission production of } \mathrm{SO}_{2} \text { when } \\
\text { switching (kg/year) }\end{array}$ \\
\hline DEC & Diesel fuel energy content $(\mathrm{kJ} / \mathrm{kg})$ \\
\hline $\mathrm{EF}_{\mathrm{CO}_{2}}$ & Emission factor of $\mathrm{CO}_{2}(\mathrm{~kg} / \mathrm{kWh})$ \\
\hline $\mathrm{EF}_{\mathrm{CO}}$ & Emission factor of $\mathrm{CO}(\mathrm{kg} / \mathrm{kWh})$ \\
\hline $\mathrm{EF}_{\mathrm{SO}_{2}}$ & Emission factor of $\mathrm{SO}_{2}(\mathrm{~kg} / \mathrm{kWh})$ \\
\hline $\mathrm{EF}_{\mathrm{NO}_{\mathrm{x}}}$ & Emission factor of NOx $(\mathrm{kg} / \mathrm{kWh})$ \\
\hline TABS $_{\mathrm{RM}}$ & Total annual bill saving RM/year \\
\hline $\mathrm{UFP}_{\mathrm{f}}$ & Unit fuel price (RM/Liter or RM/kg) \\
\hline$\% \mathrm{~B}_{\mathrm{FS}}$ & Percentage of biomass fuel switching \\
\hline$\% \mathrm{D}_{\mathrm{FS}}$ & Percentage of diesel fuel switching \\
\hline$\% \mathrm{NG}_{\mathrm{FS}}$ & Percentage of natural gas switching \\
\hline$\rho_{\mathrm{f}}$ & Density of a particular fuel $\left(\mathrm{kg} / \mathrm{m}^{3}\right)$ \\
\hline 0.4 & $\begin{array}{l}\text { Percentage of } \mathrm{CO}_{2} \text { emission avoided by palm oil when } \\
\text { replacing fossil fuel }\end{array}$ \\
\hline 3600 & Conversion factor from $\mathrm{kWh}$ to $\mathrm{kJ}$ \\
\hline
\end{tabular}

\section{ACKNOWLEDGMENTS}

The authors would like to thank the lecturers and staff of faculty of engineering, University of Malaya, for their valuable assistance.

\section{REFERENCES}

[1] Saidur, R., Rahim, N.A., Masjuki, H.H., Mekhilef, S., Ping, H.W., Jamaluddin M.F., 2009. End-use energy analysis in the Malaysian industrial sector. Energy 34, 153-158.

[2] Asia Pacific Energy Research Centre (APEC), 2006. Energy demand and supply Outlook. [Online] Available at: http://www.ieej.or.jp/aperc/2006pdf/Outlook2006/Wh ole_Report.pdf , [Accessed: $15^{\text {th }}$ September 2009].

[3] Saidur, R., Rahim, N.A., Ping, H.W., Jahirul, M.I., Mekhilef, S., Masjuki, H.H., 2009. Energy and emission analysis for industrial motors in Malaysia. Energy Policy 37, 3650-3658.

[4] Masjuki, H.H., Mahlia, T.M.I., Choudhury, I.A., Saidur, R., 2002. Potential $\mathrm{CO}_{2}$ reduction by fuel substitution to generate electricity in Malaysia. Energy Conversion and Management 43, 763-770.

[5] Eggertson, B., 2006, Fuel switching what's wrong with that?. Refocus 7, 64-65.

[6] Delarue, E., D'haeseleer, W., 2008. Greenhouse gas emission reduction by means of fuel switching in electricity generation: Addressing the potentials. Energy Conversion and Management 49, 843-853.

[7] Demirbas, A., 2005. Potential applications of renewable energy sources, biomass combustion problems in boiler power systems and combustion related environmental issues. Progress in Energy and Combustion Science 31, 171-192.

[8] Shuit, S.H., Tan, K.T., Lee, K.T., Kamaruddin, A.H., 2009. Oil palm biomass as a sustainable energy source: A Malaysian case study. Energy 34, 1225 1235.

[9] Zutphen, H v., Wibrans, R., 2007. The carbon balance: the new centre of attention. [Online] Available at: http://www.malaysiapalmoil.org/pdf/carboncapital $\% 2$ 0solutions.pdf, [Accessed: $5^{\text {th }}$ September 2009].

[10] PTM, 2007, Personal Communication. Pusat Tenaga Malaysia (PTM), Malaysia

[11] PTM, 2009. CDM Potential in the Energy Sector. Pusat Tenaga Malaysia (PTM), Malaysia.

[12] Mahlia, T.M.I., 2002. Emissions from electricity generation in Malaysia. Renewable Energy 27, 293300 . 